\title{
Severe Impairment of NMDA Receptor Function in Mice Carrying Targeted Point Mutations in the Glycine Binding Site Results in Drug-Resistant Nonhabituating Hyperactivity
}

\author{
Theresa M. Ballard, ${ }^{1 *}$ Meike Pauly-Evers, ${ }^{2 *}$ Guy A. Higgins, ${ }^{1}$ Abdel-Mouttalib Ouagazzal, ${ }^{1}$ Vincent Mutel, ${ }^{1}$ \\ Edilio Borroni, ${ }^{1}$ John A. Kemp, ${ }^{1}$ Horst Bluethmann, ${ }^{2}$ and James N. C. Kew ${ }^{1}$ \\ 1Preclinical CNS Research and ${ }^{2}$ Roche Genetics, F. Hoffmann-La Roche Limited, CH-4070 Basel, Switzerland
}

NMDA receptor hypofunction has been implicated in the pathophysiology of schizophrenia, and pharmacological and genetic approaches have been used to model such dysfunction. We previously have described two mouse lines carrying point mutations in the NMDA receptor glycine binding site, Grin $1^{D 481 N}$ and Grin $1^{K 483 Q}$, which exhibit 5- and 86-fold reductions in receptor glycine affinity, respectively. Grin $1^{D 481 N}$ animals exhibit a relatively mild phenotype compatible with a moderate reduction in NMDA receptor function, whereas Grin $1^{K 483 Q}$ animals die shortly after birth. In this study we have characterized compound heterozygote Grin $1^{D 481 N / K 483 Q}$ mice, which are viable and exhibited biphasic NMDA receptor glycine affinities compatible with the presence of each of the two mutated alleles. Grin $1^{D 481 N / K 483 Q}$ mice exhibited a marked NMDA receptor hypofunction revealed by deficits in hippocampal longterm potentiation, which were rescued by the glycine site agonist D-serine, which also facilitated NMDA synaptic currents in

The ionotropic glutamate receptors comprise the NMDA, AMPA, and kainate receptor families. NMDA receptors are heteromers composed of an NMDAR1 subunit and one or more of the four NR2 subunits (NR2A-NR2D) (Kutsuwada et al., 1992; Monyer et al., 1992). NMDA receptors are unique among ligand-gated ion channels in their requirement for an obligatory coagonist, glycine (Johnson and Ascher, 1987; Kleckner and Dingledine, 1988), in addition to the synaptically released neurotransmitter glutamate for receptor activation. Electrophysiological studies have demonstrated that NMDA receptor activation requires the occupation of two independent glycine sites and two independent glutamate sites (Benveniste and Mayer, 1991; Clements and Westbrook, 1991). Thus the minimal requirement for a functional NMDA receptor is likely to be a tetramer (Laube et al., 1998) composed of two NMDAR1 and two NR2 subunits that contain the glycine (Kuryatov et al., 1994; Wafford et al., 1995; Hirai et al., 1996; Kew et al., 2000) and glutamate (Laube et al., 1997; Anson et al., 1998) binding sites, respectively.

\footnotetext{
Received Feb. 7, 2002; revised April 22, 2002; accepted May 1, 2002.

We thank Marie-Claire Pflimlin, Urs Humbel, Sylvie Chaboz, Hans Ehrsam, Patricia Glaentzlin, Caroline Kuhn, Bernard Morand, Stefanie Saenger, and Yeter Kolb for expert technical assistance.

*T.M.B. and M.P.-E. contributed equally to this work.

Correspondence should be addressed to James N. C. Kew at his present address: Psychiatry Centre for Excellence, GlaxoSmithKline, New Frontiers Science Park, Third Avenue, Harlow, Essex CM19 5AW, UK. E-mail: james.n.kew@gsk.com.

Abdel-Mouttalib Ouagazzal's present address: Institut de Génétique et de Biologie Moléculaire et Cellulaire, 64704 Illkirch, France.

Copyright (C) 2002 Society for Neuroscience $\quad 0270-6474 / 02 / 226713-11 \$ 15.00 / 0$
}

mutant, but not in wild-type, mice. Analysis of striatal monoamine levels revealed an apparent dopaminergic and serotonergic hyperfunction. Behaviorally, Grin $1^{D 481 N / K 483 Q}$ mice were insensitive to acute dizocilpine pretreatment and exhibited increased startle response but normal prepulse inhibition. Most strikingly, mutant mice exhibited a sustained, nonhabituating hyperactivity and increased stereotyped behavior that were resistant to suppression by antipsychotics and the benzodiazepine site agonist Zolpidem. They also displayed a disruption of nest building behavior and were unable to perform a cued learning paradigm in the Morris water maze. We speculate that the severity of NMDA receptor hypofunction in these mice may account for their profound behavioral phenotype and insensitivity to antipsychotics.

Key words: NMDA receptor; glycine site; schizophrenia; NMDAR1; Grin1; antipsychotics
Pharmacological studies have demonstrated a critical role for NMDA receptor activation in both the induction of certain forms of long-term potentiation (LTP) and learning and memory (Morris et al., 1986; Larson and Lynch, 1988). In addition, the blockade of NMDA receptors in vivo by uncompetitive ion channel blockers such as phencyclidine (PCP) and dizocilpine induces behaviors in rats and mice that include hyperlocomotion, stereotypy, and reduction of prepulse inhibition and that are accompanied by the disruption of neuronal monoaminergic systems (Hiramatsu et al., 1989; Corbett et al., 1995; Geyer et al., 2001). PCP elicits a behavioral syndrome in man that resembles schizophrenia, incorporating positive (e.g., hallucinations, delusions, paranoia), negative (e.g., anhedonia, social isolation, flat affect), and cognitive symptoms (Javitt and Zukin, 1991). These observations provided the basis for the glutamate dysfunction hypothesis for the pathophysiology of schizophrenia; accordingly, PCP- or dizocilpine-treated animals have been adopted as models of the disorder.

Mutant mice exhibiting reduced NMDA receptor expression have been shown to exhibit diverse phenotypes, including developmental abnormalities and postnatal lethality (Forrest et al., 1994; Li et al., 1994; Kutsuwada et al., 1996), impaired synaptic plasticity, and learning and memory (Sakimura et al., 1995; Tsien et al., 1996) and behavioral changes that might model schizophrenia (Mohn et al., 1999; Miyamoto et al., 2001). Mutant mice expressing reduced levels of NMDAR1 exhibited hyperlocomotion, increased stereotypy, and abnormalities in social and sexual interactions that were ameliorated by antipsychotic pharmaco- 
therapy (Mohn et al., 1999). Mutant mice lacking the NR2A subunit also exhibited a neuroleptic-sensitive hyperlocomotion together with an apparent hyperfunction of monoaminergic activity in the striatum and frontal cortex (Miyamoto et al., 2001).

We previously have described two mouse lines generated by site-directed mutagenesis carrying point mutations in the glycine binding site of the NMDAR1 subunit (Grin1, according to the Mouse Genome Database) (Kew et al., 2000). Homozygous mutant $G r i n 1^{D 481 N}$ animals, which exhibited a fivefold reduction in receptor glycine affinity, displayed mild deficits in LTP induction and spatial learning and increased startle reactivity but normal locomotor activity and prepulse inhibition. Homozygous mutant Grin $1^{K 483 Q}$ animals, which exhibited an 86 -fold reduction in receptor glycine affinity, did not feed and died within a few days of birth. Here we describe compound heterozygote Grin $1^{D 481 N / K 483 Q}$ mice. These animals are viable and exhibited biphasic NMDA receptor glycine affinities compatible with the presence of each of the mutant Grin1 subunits, although receptor glutamate affinity was unchanged.

\section{MATERIALS AND METHODS}

Generation of Grin1 compound heterozygote mice. Grin $1^{D 481 N / D 481 N}$ and Grin $1^{K 483 Q /+}$ mice were generated as described previously (Kew et al., 2000). Grin $1^{D 481 N / D 481 N}$ were mated with Grin $1^{K 483 Q /+}$, resulting in offspring carrying one of the mutations on each allele $\left(\operatorname{Grin} 1^{D 481 N / K 483 Q}\right)$ or the D481N mutation on just one allele (Grin1 $\left.1^{D 481 N /+}\right)$. Mice were genotyped by PCR on genomic tail DNA by using the primer described previously (Kew et al., 2000) and an additional primer specific for the K483Q mutation (5'-CCG CTC CTG TGT GCC AAA CTG-3'). Grin $1^{D 481 N / K 483 Q}$ can be distinguished from Grin $1^{\text {D481N/+ }}$ by an additional amplicon of $\sim 200$ bp size. Grin $1^{D 481 N / K 483 Q}$ were fed with wet food starting at approximately day 15 because they were smaller and weaker than heterozygous littermates and had difficulties in reaching normal food pellets and water supplied on top of the cage. C57BL/6J $\times 129 / \mathrm{Ola}$ F1 hybrids were used as wild-type controls.

Whole-cell voltage-clamp recordings from acutely dissociated hippocampal neurons. Brain slices $(400 \mu \mathrm{m})$ from 5- to 12-d-old wild-type or Grin1 $1^{D 481 N / K 483 Q}$ mice were cut with a vibratome in an ice-cold solution that contained (in mM): $125 \mathrm{NaCl}, 2.5 \mathrm{KCl}, 2 \mathrm{CaCl}_{2}, 1 \mathrm{MgCl}_{2}, 1.25$ $\mathrm{NaH}_{2} \mathrm{PO}_{4}, 26 \mathrm{NaHCO}_{3}$, and $25 \mathrm{D}$-glucose pH-adjusted to 7.4 with oxycarbon $\left(95 \% \mathrm{O}_{2} / 5 \% \mathrm{CO}_{2}\right)$; subsequently, the slices were incubated at $20^{\circ} \mathrm{C}$ in the same solution. When needed for electrophysiological experiments, the hippocampus was dissected out of each slice, and neurons were dissociated as described previously (Kew et al., 1998). Whole-cell voltage-clamp recordings were performed as described previously (Kew et al., 1998).

Equilibrium concentration-response curves. Best-fit lines were computed for equilibrium concentration-response data by using a twoequivalent binding site model for monophasic fits:

$$
I=I_{\max } /\left(1+\left(m K_{\mathrm{D}} /[A]\right)\right)^{2},
$$

where $m K_{\mathrm{D}}$ is the microscopic dissociation constant and $[A]$ is the agonist concentration. Data were fit with a $2 \times$ two-equivalent binding site model for biphasic fits:

$$
I=I_{\max (\mathrm{H})} /\left(1+\left(m K_{\mathrm{D}(\mathrm{H})} /[A]\right)\right)^{2}+I_{\max (\mathrm{L})} /\left(1+\left(m K_{\mathrm{D}(\mathrm{L})} /[A]\right)\right)^{2},
$$

where $I_{\max (\mathrm{H})}$ and $I_{\max (\mathrm{L})}$ are the current amplitudes of the high- and low-affinity components of the concentration-response curve and $m K_{\mathrm{D}(\mathrm{H})}$ and $m K_{\mathrm{D}(\mathrm{L})}$ are the microscopic dissociation constants for the high- and low-affinity components of the curve.

Long-term potentiation. Hippocampal slices $(400 \mu \mathrm{m})$ were cut from 6to 7-month-old mice with a Sorvall tissue chopper. Slices were perfused at $35^{\circ} \mathrm{C}$ with a simple salt solution containing (in $\mathrm{mm}$ ): $124 \mathrm{NaCl}, 2.5 \mathrm{KCl}$, $2 \mathrm{MgSO}_{4}, 2.5 \mathrm{CaCl}_{2}, 1.25 \mathrm{KH}_{2} \mathrm{PO}_{4}, 26 \mathrm{NaHCO}_{3}, 10$ glucose, and 4 sucrose gassed with $95 \% \mathrm{O}_{2} / 5 \% \mathrm{CO}_{2}, \mathrm{pH} 7.4$. The CA1 stratum radiatum was stimulated $(0.05 \mathrm{~Hz}, 100 \mu \mathrm{sec})$ at a stimulus strength adjusted to evoke field EPSPs equal to $30 \%$ of the relative maximum amplitude without superimposed population spike. Field EPSPs were recorded from the CA1 stratum radiatum with a glass micropipette (1-3 M $\Omega$ ) containing $2 \mathrm{M} \mathrm{NaCl}$. After stable baseline recordings the LTP was induced by using a theta burst stimulation (TBS) paradigm consisting of two stimulus patterns spaced by $8 \mathrm{sec}$. Each pattern consisted of 10 of the $50 \mathrm{msec}$ stimulus trains at $100 \mathrm{~Hz}$, each separated by $150 \mathrm{msec}$. The duration of the stimulation pulses was doubled during the tetanus. Results are expressed as means \pm SE of the field EPSP slope as a percentage of the baseline values recorded $10 \mathrm{~min}$ before TBS.

Cortical wedge experiments. Experiments with cortical wedges were performed with the greased gap technique as described previously (Kew et al., 2000). Coronal slices $(500 \mu \mathrm{m})$ were cut from a 3- to 4-mm-thick block of cerebral cortex/striatum with a vibratome. The tissue was submerged at all times in a simple salt solution containing (in mM): 124 $\mathrm{NaCl}, 2.5 \mathrm{KCl}, 2 \mathrm{MgSO}_{4}, 2.5 \mathrm{CaCl}_{2}, 1.25 \mathrm{KH}_{2} \mathrm{PO}_{4}, 26 \mathrm{NaHCO}_{3}, 10$ glucose, and 4 sucrose gassed with $95 \% \mathrm{O}_{2} / 5 \% \mathrm{CO}_{2}, \mathrm{pH} 7.4$. Tissue wedges $\sim 1 \mathrm{~mm}$ wide consisting of frontoparietal motor cortex, corpus callosum, and underlying striatal matter were dissected from the cortical slices. The wedges were mounted in a Perspex perfusion chamber and perfused continuously with a modified salt solution containing $300 \mathrm{~nm}$ tetrodotoxin and $1.75 \mathrm{~mm} \mathrm{CaCl}_{2}$ and lacking $\mathrm{MgSO}_{4}$. Population depolarizations of the cortical tissue were evoked by 1-min-duration applications of $20 \mu \mathrm{M}$ NMDA or $6 \mu \mathrm{M}$ AMPA, were recorded by using Agar/ $\mathrm{Ag} / \mathrm{AgCl}$ electrodes connected to a direct current amplifier, and were acquired by using MacLab8 software. AMPA applications were made at the beginning and end of the experiments to control for the stability of the preparation. All experiments were performed at room temperature.

Whole-cell hippocampal slice recordings. Hippocampal slices from 26- to 50-d-old mice were cut in a simple salt solution [containing (in mM): 124 $\mathrm{NaCl}, 2.5 \mathrm{KCl}, 2.5 \mathrm{CaCl}_{2}, 1.25 \mathrm{KH}_{2} \mathrm{PO}_{4}, 6 \mathrm{MgCl}_{2}, 2 \mathrm{MgSO}_{4}, 26$ $\mathrm{NaHCO}_{3}$, and 15 glucose gassed with $95 \% \mathrm{O}_{2} / 5 \% \mathrm{CO}_{2}, \mathrm{pH}$ 7.4] with a vibratome. Slices were maintained at room temperature in a storage chamber for a least $1 \mathrm{hr}$. Then single slices were placed in a recording chamber perfused at room temperature with simple salt solution without $\mathrm{Mg}^{2+}$ salts and with $10 \mu \mathrm{M} \mathrm{NBQX}$ and $50 \mu \mathrm{M}$ picrotoxin. Patch pipettes had resistances of $\sim 2-4 \mathrm{M} \Omega$ when filled with patch pipette solution [containing (in mM): $120 \mathrm{CsF}, 10 \mathrm{CsCl}, 11$ EGTA, $0.5 \mathrm{CaCl}_{2}, 10 \mathrm{HEPES}$, and $5 \mathrm{QX} 314 \mathrm{pH}$-adjusted to 7.25 with $\mathrm{CsOH}$ and osmolarity-adjusted to 290 mOsm]. Whole-cell recordings were made from CA1 pyramidal cell soma visualized via a $40 \times$ water immersion objective and infrared differential interference contrast optics (Olympus BX50WI, Schwerzenbach, Switzerland), using an Axopatch 1D amplifier (Axon Instruments, Foster City, CA). The CA1 stratum radiatum was stimulated $(0.03 \mathrm{~Hz}$, $100 \mu \mathrm{sec})$ at a stimulus strength adjusted to evoke NMDA field EPSCs of $\sim 500 \mathrm{pA}$. At the end of each recording D-AP5 (50 $\mu \mathrm{M})$ was applied to confirm that the currents were NMDA receptor-mediated. Synaptic events were recorded onto digital audio tape (DTR-1204; BioLogic, Claiz, France). Data acquisition and analysis were performed with pClamp7 (Axon Instruments).

$\left[{ }^{3} \mathrm{H}\right]$-dizocilpine binding. Wild-type and mutant mice forebrains were homogenized individually at $4^{\circ} \mathrm{C}$ in 25 volumes of $50 \mathrm{~mm}$ Tris- $\mathrm{HCl}$ and $10 \mathrm{~mm}$ EDTA, pH 7.1, buffer with a polytron $(10,000 \mathrm{rpm}, 30 \mathrm{sec})$. The homogenate was centrifuged at $48,000 \times g$ for $10 \mathrm{~min}$, and the pellet was rehomogenized as above and incubated for $10 \mathrm{~min}$ at $37^{\circ} \mathrm{C}$. After centrifugation the pellet was homogenized as above, and the homogenate was frozen at $-80^{\circ} \mathrm{C}$. $\left[{ }^{3} \mathrm{H}\right]$-dizocilpine saturation isotherms were obtained by incubating various amounts of the radioligand $(0.3-100 \mathrm{nM}$, final concentration) in the presence of $10 \mathrm{mg}$ of brain membranes for 2 $\mathrm{hr}$ at room temperature in a $5 \mathrm{~mm}$ Tris- $\mathrm{HCl}, 3 \mathrm{~mm}$ glycine, and $100 \mu \mathrm{M}$ glutamate, $\mathrm{pH} 7.4$, binding buffer. The nonspecific binding was measured in the presence of $100 \mu \mathrm{M}$ 1-[1-(2-thienyl)cyclohexyl]piperidine (TCP). After incubation the membranes were filtered on GF/B glass fiber filters preincubated for $1 \mathrm{hr}$ in a polyethyleneimine $0.1 \%$ solution. The filters were washed three times with $3 \mathrm{ml}$ of cold binding buffer, and the radioactivity bound to the membranes was measured by liquid scintillation counting. The binding parameters $K_{\mathrm{D}}$ and $B_{\max }$ were obtained from the fit to the data of the equation of a rectangular hyperbola (one-site model) by nonlinear regression.

Tissue levels of monoamines. Mice were decapitated. The brains were removed quickly from the skull, briefly washed in ice-cold saline, and laid down on a cooled $\left(4^{\circ} \mathrm{C}\right)$ metal plate where they were dissected rapidly to remove the striatum and frontal cortex. The dissected brain regions were frozen, weighed, and stored at $-80^{\circ} \mathrm{C}$ until analysis. The contents of monoamines and their metabolites were determined by using an HPLC system equipped with an electrochemical detector (Coulochem II detector, model 5200; ESA, Chelmsford, MA) essentially as described by Da Prada et al. (1989). Briefly, the striata and frontal cortices were homogenized with an ultrasonic processor in $0.1 \mathrm{M}$ perchloric acid containing 
$0.5 \mathrm{~mm}$ EDTA disodium and $50 \mathrm{ng} / \mathrm{ml}$ of 3,4-dihydroxybezylamine as an internal standard. The homogenates were centrifuged at $51,000 \times g$, and $5 \mu \mathrm{l}$ of the supernatant was injected in the HPLC. Monoamines and their metabolites were separated on a reverse phase ODS column (YMC-Pack, S-3 $\mu \mathrm{M}, 120 \mathrm{~A}$; Stagroma, Switzerland). The column temperature was maintained at $33^{\circ} \mathrm{C}$. The mobile phase was $34 \%$ citric acid $0.1 \mathrm{M}, 48 \%$ $\mathrm{Na}_{2} \mathrm{HPO}_{4} 0.1 \mathrm{M}, 18 \%$ methanol, $50 \mathrm{mg} / \mathrm{l}$ EDTA, and $45 \mathrm{mg} / 1$ sodium octylsulfate, $\mathrm{pH} 4.5$; the flow rate was set at $0.45 \mathrm{ml} / \mathrm{min}$. The potential settings of the analytical cell (model 5011; ESA) were $+0.45 \mathrm{~V}$ (first electrode) and $-0.3 \mathrm{~V}$ (second electrode). Monoamines and their metabolites were read as the second electrode output signal.

Neurological assessment. The mice were assessed in a number of neurological tests, including flexion reflex, grip strength $(\mathrm{g})$, and time $(\mathrm{sec})$ spent on a rotarod at 16 and $32 \mathrm{rpm}$ (methods as described by Higgins et al., 2001); for the horizontal wire test the mice were held by the tail and required to grip and hang from a $1.5 \mathrm{~mm}$ in diameter bar fixed in a horizontal position at a height of $30 \mathrm{~cm}$ above the surface for a maximum period of $1 \mathrm{~min}$. The latency for the mice to fall was measured, and a cutoff of either $60 \mathrm{sec}$ or the highest fall latency score from three attempts was used. Body weight $(\mathrm{gm})$ was checked weekly in a second group of mice from an age of 9-24 weeks. Spontaneous locomotor activity was measured in activity chambers $(36 \times 24 \times 19 \mathrm{~cm}$, $\mathrm{L} \times \mathrm{W} \times \mathrm{H}$; Benwick Electronics, UK) containing sawdust bedding for a $1 \mathrm{hr}$ period. Mobile counts were measured by the interruption of vertically and horizontally located photo beams placed around the chamber.

Nest building. It was noted while testing the animals that wild-type mice consistently made nests by shredding a tissue that was provided in the cage, whereas most of the Grin1 $1^{D 481 N / K 483 Q}$ mice did not build nests. To quantify this, we placed a folded piece of tissue paper into each cage, and $24 \mathrm{hr}$ later we assessed the nests.

Twenty-four hour locomotor activity. The mice were placed into a novel test chamber that consisted of a Plexiglas box $(20 \times 20 \times 27 \mathrm{~cm})$ with sawdust bedding on the floor. The animal's movement was recorded by using an electronic monitoring system (Omnitech Electronics, Columbus, $\mathrm{OH}$ ). Movement of the animal resulted in interruption of an array of photo beams from vertically and horizontally located infrared sources placed around the test chamber. Total distance traveled (in centimeters) and stereotypy counts were measured. Animals were placed into the boxes at 6:00 A.M. for a $24 \mathrm{hr}$ period. The room light was on from 6:00 A.M. to 6:00 P.M. and was switched off automatically from 6:00 P.M. to 6:00 A.M.; this corresponds exactly with the animals' normal light/dark cycle in the holding rooms. Food pellets $(45 \mathrm{mg})$ were scattered over the floor, and water was available ad libitum from a drinking bottle that did not interfere with the activity system.

Locomotor activity: drug studies. The mice were tested via a Latin squares design twice weekly with at least a $2 \mathrm{~d}$ interval between test sessions. Dizocilpine $(0.1,0.3 \mathrm{mg} / \mathrm{kg}$, i.p. $)$ was administered to wild-type $(n=12)$ and Grin1 ${ }^{D 481 N / K 483 Q}(n=7)$ mice immediately before testing for a $90 \mathrm{~min}$ period. Amphetamine $(1,3 \mathrm{mg} / \mathrm{kg}$, i.p.) was administered to wild-type $(n=11)$ and $\operatorname{Grin} 1^{D 481 N / K 483 Q}(n=5)$ mice $10 \mathrm{~min}$ before testing for a $1 \mathrm{hr}$ period. Clozapine $(0.1,0.3,1 \mathrm{mg} / \mathrm{kg}$, i.p.) was administered to wild-type $(n=13)$ and $\operatorname{Grin1} 1^{D 481 N / K 483 Q}(n=12)$ mice $30 \mathrm{~min}$ before testing for a $1 \mathrm{hr}$ period. Haloperidol $(0.03,0.1,0.3 \mathrm{mg} / \mathrm{kg}$, i.p.) was administered to wild-type $(n=10)$ and $\operatorname{Grin1} 1^{D 481 N / K 483 Q}(n=6)$ mice 30 min before testing for a $1 \mathrm{hr}$ period. M100907 (0.003, 0.03, 0.3 $\mathrm{mg} / \mathrm{kg}$, i.p.) was administered to wild-type $(n=12)$ and Grin1 $1^{D 481 N / K 483 Q}$ $(n=11)$ mice $30 \mathrm{~min}$ before testing for a $1 \mathrm{hr}$ period. Zolpidem $(3,10$ $\mathrm{mg} / \mathrm{kg}$, i.p.) was administered to wild-type $(n=11)$ and $\operatorname{Grin1}^{D 481 N / K 483 Q}$ $(n=5)$ mice immediately before testing for a $1 \mathrm{hr}$ period.

Prepulse inhibition. Testing was conducted in eight startle devices (SRLAB; San Diego Instruments, San Diego, CA), each consisting of a Plexiglas cylinder $(d=8.8 \mathrm{~cm})$ mounted on a Plexiglas platform in a ventilated sound-attenuated cubicle with a high-frequency loudspeaker (28 cm above the cylinder) producing all acoustic stimuli. Movements within the cylinder were detected and transduced by a piezoelectric accelerometer attached to the Plexiglas base, digitized, and stored by the computer. Beginning at the stimulus onset, 150 of the $1 \mathrm{msec}$ readings were recorded to obtain the startle amplitude (Ouagazzal et al., 2001). The first protocol was used to look at the effect of different prepulse intensities $(74,82$, and $90 \mathrm{~dB})$ on the startle pulse $(110 \mathrm{~dB}$; prepulsepulse interval, $100 \mathrm{msec}$ ). Then the mice were tested in a second prepulse inhibition (PPI) protocol, using a variable prepulse-pulse interval (interstimulus interval: 30,100 , and $300 \mathrm{msec}$ ); prepulse intensity was fixed at $90 \mathrm{~dB}$.
Water maze: cued acquisition. The ability of the wild-type $(n=10)$ and the Grin1 $1^{D 481 N / K 483 Q}(n=9)$ mice to learn to swim to and climb onto a visible, flagged platform $(7 \mathrm{~cm}$ in diameter $)$ in a water maze $(1 \mathrm{~m} \mathrm{in}$ diameter) was assessed. The platform was moved to a different position in the maze on each trial. Cued learning consisted of four sessions of training over 2 consecutive days; each session consisted of three trials (maximum duration of $60 \mathrm{sec}$ ) separated by a $10 \mathrm{~min}$ intertrial interval. All data were captured and analyzed by video tracking software (HVS Systems, UK).

Statistics. Behavioral observations were recorded among the following: mean values $\pm \mathrm{SE}$ and analyzed with an unpaired $t$ test, median values with interquartile ranges and analyzed with a Mann-Whitney $U$ test, or proportion of each group and analyzed with a $\chi^{2}$ test. Locomotor activity data (total distance and total stereotypy counts) were analyzed with a two-factor (Genotype and Dose) ANOVA with repeated measures. Comparisons of dose effects in each genotype were undertaken with a repeated measures ANOVA, followed in significant cases by paired $t$ tests. PPI data were analyzed with an ANOVA, followed in significant cases by a post hoc Newman-Keuls test. Percentage of PPI was calculated according to the formula: [100 $\times($ ST110-PP74, PP82, PP90/ST110] (variable prepulse intensity experiment) or $[100 \times($ ST110-ISI30, ISI100, ISI300/ST110] (variable interstimulus interval experiment). Water maze data were analyzed with a two-factor ANOVA (Genotype and Session) with repeated measures. A $p$ value of $<0.05$ was accepted as statistically significant.

\section{RESULTS}

\section{Severe reduction in NMDA receptor glycine affinity in Grin1 $^{D 481 N / K 483 Q}$ mice}

Glycine and glutamate concentration-response analysis was performed by using whole-cell patch-clamp recordings from acutely dissociated hippocampal neurons from 7-to 10-d-old Grin1 $1^{D 481 N / K 483 Q}$ mice. Glycine concentration-response curves were generated by rapidly jumping from a control solution to one containing $100 \mu \mathrm{M}$ NMDA in the presence of increasing concentrations of glycine in both the control and NMDA-containing solutions. Glycine concentration-response curves were biphasic and were better fit by a $2 \times$ two-equivalent binding site model than a monophasic two-equivalent binding site model $(p<0.1 ; F$ test). The fitted curve through the mean data yielded high- and low-affinity $m K_{\mathrm{D}}$ values of 0.22 and $3.41 \mu \mathrm{M}$, respectively, with amplitudes of the high- and low-affinity components of 16 and $84 \%$, respectively (Fig. $1 A$ ). These glycine affinities are in good agreement with those we have reported previously for homozygous Grin1 $1^{D 481 N}\left(m K_{\mathrm{D}}=0.19 \mu \mathrm{M}\right)$ and Grin1 ${ }^{K 483 Q}\left(m K_{\mathrm{D}}=3.26\right.$ $\mu \mathrm{M})$ mice (Kew et al., 2000).

Glutamate concentration-response curves were constructed by jumping rapidly from a control solution into one containing increasing concentrations of glutamate in the continuous presence of $100 \mu \mathrm{M}$ glycine and $10 \mu \mathrm{M}$ NBQX in the control and glutamatecontaining solutions. Glutamate concentration-response curves were monophasic, and a fitted curve through the mean data yielded an $m K_{\mathrm{D}}$ of $3.2 \mu \mathrm{M}$ (Fig. $1 B$ ). The mean $p m K_{\mathrm{D}}$ value of $5.49 \pm 0.03$ $(n=3)$ was not significantly different from that we have described previously (Kew et al., 2000) for control mice, $5.70 \pm 0.08$ ( $n=9$; two-tailed $t$ test; $p>0.1$ ).

To examine the relative level of NMDA receptor glycine site occupancy in brain slices from control and Grin $1^{D 481 N / K 483 Q}$ mice, we used a greased gap cortical wedge technique. In cortical wedges from wild-type animals the level of occupancy of the glycine site is such that the application of NMDA $(20 \mu \mathrm{M})$ alone results in a robust depolarization. The addition of the NMDA glycine site agonist D-serine, which is not taken up by the GLYT1 glycine transporter (Supplisson and Bergman, 1997), at up to 300 $\mu \mathrm{M}$ resulted in a small, nonsignificant potentiation of control NMDA responses with mean depolarizations of $1.67 \pm 0.17$ and 

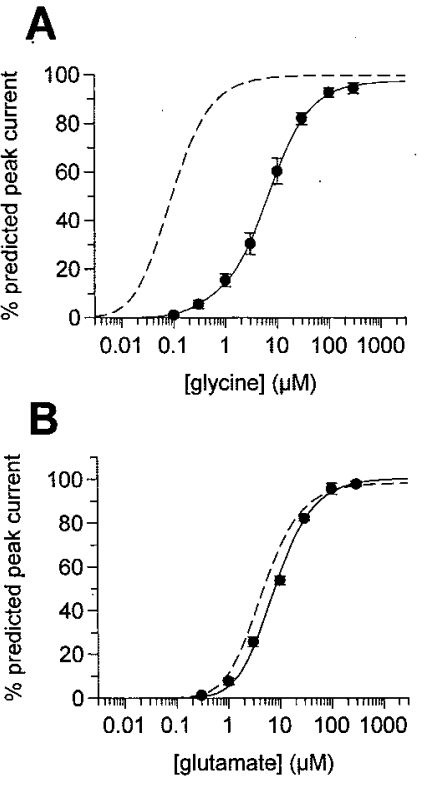

Figure 1. Glycine and glutamate concentration-response curves from Grin $1^{D 481 N / K 483 Q}$ mouse hippocampal neurons. $A$, Mean glycine concentration-response data from Grin1 $1^{D 481 N / K 483 Q}$ mice. Mean \pm SE peak currents elicited by the application of $100 \mu \mathrm{M}$ NMDA in the presence of increasing concentrations of glycine $(n=7)$ are expressed as a function of the maximum peak response derived from a fitted curve of the peak glycine concentration-response data for each individual neuron, using the $2 \times$ two-equivalent binding site model. A curve fit with the $2 \times$ twoequivalent binding site model yielded $m K_{\mathrm{D}}$ values and relative amplitudes of $0.22 \mu \mathrm{M}(16 \%)$ and $3.41 \mu \mathrm{M}(84 \%)$ for the high- and low-affinity components, respectively. The dashed line shows a representative monophasic glycine concentration-response curve from control wild-type hippocampal neurons $\left(m K_{\mathrm{D}}=38 \mathrm{~nm}\right)$ (Kew et al., 2000). B, Mean glutamate concentration-response data from $\operatorname{Grin} 1^{D 481 N / K 483 Q}$ mice. A curve fit with the two-equivalent binding site model yielded an $m K_{\mathrm{D}}$ value of $3.2 \mu \mathrm{M}$. Mean \pm SE peak currents elicited by the application of increasing concentrations of glutamate in the continual presence of 100 $\mu \mathrm{M}$ glycine and $10 \mu \mathrm{M}$ NBQX $(n=3)$ are expressed as a function of the maximum peak response derived from a fitted curve of the peak glutamate concentration-response data for each individual neuron with the two-equivalent binding site model. The dashed line shows representative glutamate concentration-response data from control wild-type hippocampal neurons $\left(m K_{\mathrm{D}}=1.9 \mu \mathrm{M}\right)(\mathrm{Kew}$ et al., 2000).

$1.91 \pm 0.23 \mathrm{mV}(n=22)$ under control conditions and in the presence of $300 \mu \mathrm{M}$ D-serine, respectively (Fig. $2 A$ ). The addition of D-serine to cortical wedges from $\operatorname{Grin} 1^{D 481 N / K 483 Q}$ mice resulted in a marked concentration-dependent increase in response amplitude with mean depolarizations of $1.19 \pm 0.11$ and $2.70 \pm$ $0.33 \mathrm{mV}(n=7-14)$ under control conditions and in the presence of $300 \mu \mathrm{M}$ D-serine, respectively. Thus, whereas in cortical wedges from wild-type animals the NMDA receptor glycine site apparently is close to saturated, the D-serine-mediated potentiation of response amplitude in slices from mutant mice reveals a population of nonliganded receptors.

We next assayed the effect of D-serine on synaptically evoked NMDA receptor-mediated currents. NMDA receptor-mediated EPSCs were recorded from identified CA1 pyramidal neurons by using the whole-cell patch-clamp technique in the absence of $\mathrm{Mg}^{2+}$ and in the presence of $10 \mu \mathrm{M} \mathrm{NBQX}$ and $50 \mu \mathrm{M}$ picrotoxin. Stimulation strength was adjusted to elicit EPSCs of $\sim 500 \mathrm{pA}$ amplitude. The addition of $100 \mu \mathrm{M}$ D-serine did not affect the amplitude of EPSCs elicited in hippocampal slices from wildtype mice $(97 \pm 3 \% ; n=7)$ but resulted in a significant

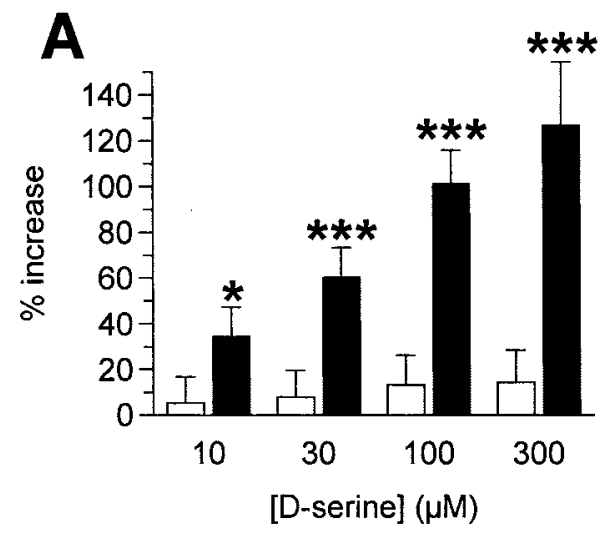

B
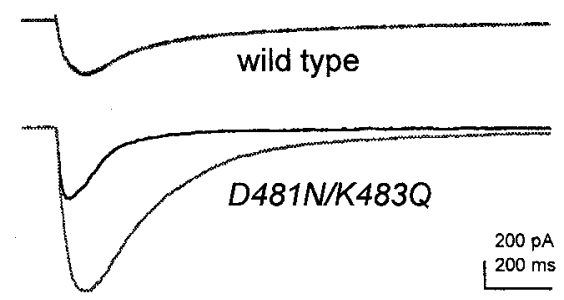

C

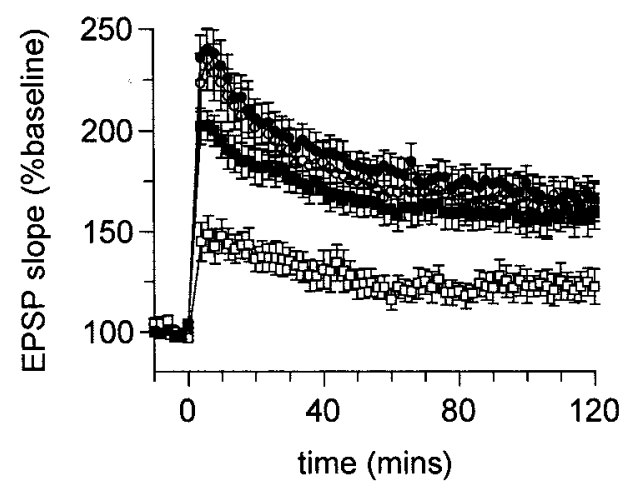

Figure 2. Reduced NMDA receptor glycine site occupancy in brain slices from Grin1 $1^{D 41 N / K 483 Q}$ mice. $A$, NMDA-induced population depolarizations in cortical wedges from wild-type (open bars, $n=22$ ) and Grin $1^{D 481 N / K 483 Q}$ mice (solid bars, $n=7-14$ ). Mean \pm SE depolarizations produced by the application of $20 \mu \mathrm{M}$ NMDA in the presence of increasing concentrations of $\mathrm{D}$-serine are expressed as a percentage increase relative to the depolarization produced by the application of $20 \mu \mathrm{M}$ NMDA alone in each individual slice (i.e., $20 \mu \mathrm{M}$ NMDA alone, $0 \%$ ). The relative increase in response amplitude after the addition of D-serine was significantly greater in $\operatorname{Grin} 1^{D 481 N / K 483 Q}$, but not wild-type, mice ${ }^{*} p<$ $0.05 ; * * * p<0.001$; two-tailed $t$ test). $B$, Representative traces illustrating NMDA receptor-mediated EPSCs recorded from CA1 pyramidal neurons in hippocampal slices from $\operatorname{Grin} 1^{D 481 N / K 483 Q}$ and wild-type mice in the absence (black lines) and presence (gray lines) of $100 \mu \mathrm{M} \mathrm{D}$-serine. EPSCs recorded from Grin $1^{D 481 N / K 483 Q}$, but not wild-type, mice were potentiated significantly in the presence of D-serine. $C$, Theta burstinduced LTP in hippocampal slices from wild-type and Grin $1^{D 481 N / K 483 Q}$ mice in the absence (open circles, $n=8$; open squares, $n=8$ ) and presence ( filled circles, $n=8$; filled squares, $n=7$ ) of $100 \mu \mathrm{M} \mathrm{D}$-serine. Where added, D-serine was present from $30 \mathrm{~min}$ before theta burst stimulation to the end of the experiment. Mean \pm SE field EPSP slopes are expressed as a percentage of baseline values recorded $10 \mathrm{~min}$ before theta burst stimulation. 
Table 1. Tissue content of dopamine, noradrenaline (NA), serotonin, and metabolites in the striatum and frontal cortex of wild-type and Grin1 ${ }^{D 481 N / K 483 Q}$ mice

\begin{tabular}{|c|c|c|c|c|}
\hline \multirow{2}{*}{$\begin{array}{l}\text { Tissue content } \\
(\mathrm{ng} / \mathrm{gm})\end{array}$} & \multicolumn{2}{|l|}{ Striatum } & \multicolumn{2}{|c|}{ Frontal cortex } \\
\hline & Wild type & $\mathrm{D} 481 \mathrm{~N} / \mathrm{K} 483 \mathrm{Q}$ & Wild type & $\mathrm{D} 481 \mathrm{~N} / \mathrm{K} 483 \mathrm{Q}$ \\
\hline Dopamine & $13279 \pm 431$ & $16981 \pm 634^{* *}$ & $56 \pm 12$ & $44 \pm 5$ \\
\hline DOPAC & $1361 \pm 23$ & $1651 \pm 45^{* *}$ & $23 \pm 2$ & $25 \pm 2$ \\
\hline HVA & $1453 \pm 45$ & $1565 \pm 160$ & $49 \pm 4$ & $48 \pm 6.4$ \\
\hline NA & $124 \pm 11$ & $210 \pm 62$ & $200 \pm 6$ & $230 \pm 12$ \\
\hline Serotonin & $1139 \pm 29$ & $1390 \pm 64^{*}$ & $411 \pm 18$ & $456 \pm 23$ \\
\hline 5-HIAA & $522 \pm 16$ & $617 \pm 29^{*}$ & $91 \pm 4$ & $94 \pm 11$ \\
\hline
\end{tabular}

Data are presented as mean \pm SE for wild-type $(n=11)$ and $\operatorname{Grin1} 1^{D 481 N / K 483 Q}(n=5)$ mice; $* p<0.05 ; * * p<0.005 ;$ two-tailed $t$ test.

\begin{tabular}{|c|c|c|}
\hline Neurological assessment & Wild type & D481N/K483Q \\
\hline Body weight (gm) & $27.6 \pm 1.0$ & $21.6 \pm 0.5^{* *}$ \\
\hline Body temperature $\left({ }^{\circ} \mathrm{C}\right)$ & $37.3 \pm 0.2$ & $37.5 \pm 0.2$ \\
\hline Flexion reflex & $14 / 14$ & $14 / 14$ \\
\hline Grip strength (g) & $154.3 \pm 6.2$ & $64.9 \pm 6.9^{* * *}$ \\
\hline Horizontal wire test $(\mathrm{sec})$ & $57(29-60)$ & $1.5(0-8)^{* * *}$ \\
\hline Rotarod-16 rpm (sec) & $120(62-120)$ & $9(5-18)^{* * *}$ \\
\hline Rotarod-32 rpm (sec) & $48(19-88)$ & $8(3-12)^{* * *}$ \\
\hline
\end{tabular}

$\overline{\text { Data are presented as mean } \pm \mathrm{SE} \text {; median with interquartile range in parentheses }}$ (Mann-Whitney $U$ test); proportion of group, $n=14$ /group. ${ }^{* *} p<0.01$; ${ }^{* * *} p<$ 0.001 ; two-tailed $t$ test.

increase $(263 \pm 13 \% ; n=8$; two-tailed $t$ test; $p<0.0001)$ of EPSC amplitude in hippocampal slices from Grin1 $1^{D 481 N / K 483 Q}$ mice (Fig. 2B).

Theta burst-induced potentiation in hippocampal slices from Grin1 $1^{D 481 N / K 483 Q}$ mice was attenuated significantly, relative to wild-type controls, throughout the post-tetanus period (ANOVA; 4-12 min, $p<0.001$; 90-120 min, $p<0.01$ ) (Fig. 2C). The deficit in LTP was rescued by the addition of $100 \mu \mathrm{M}$ D-serine before the tetanus, although post-tetanic potentiation (PTP) remained somewhat attenuated in slices from mutant mice (ANOVA; 4-12 $\min , p<0.05$; 90-120 min, $p>0.1$ ). In slices from wild-type mice the addition of D-serine had no effect on either PTP or LTP.

Saturation-binding analysis with the uncompetitive NMDA receptor antagonist $\left[{ }^{3} \mathrm{H}\right]$-dizocilpine that used mouse forebrain membranes in the presence of saturating concentrations of glutamate and glycine revealed no significant differences in $p K_{\mathrm{D}}$ : wild-type $=8.40 \pm 0.07$ and $G \operatorname{rin} 1^{D 481 N / K 483 Q}=8.46 \pm 0.06(n=$ 4 and 3, respectively) or in $B_{\max }$ values: ( $\mathrm{pmol} / \mathrm{mg}$ tissue) wildtype $=0.066 \pm 0.003$ and Grin1 $1^{D 481 N / K 483 Q}=0.070 \pm 0.04$.

We assayed the tissue content of the neurotransmitters dopamine, noradrenaline, and serotonin in the striatum and frontal cortex of mutant and wild-type mice. Levels of dopamine and serotonin and their metabolites were elevated in the striatum, but not frontal cortex, of mutant relative to wild-type mice (Table 1).

\section{Neurological assessment}

Grin1 $1^{D 481 N / K 483 Q}$ mice were impaired significantly in their performance of motor tests, such as grip strength ( $\mathrm{df}=26 ; t=9.7$; $p<0.0001)$ and rotarod at both $16 \mathrm{rpm}(\mathrm{z}=-4.2 ; p<0.0001)$ and $32 \mathrm{rpm}(\mathrm{z}=-4.1 ; p<0.0001)$ compared with wild-type mice (Table 2). However, this impairment also may be a consequence of their hyper-reactivity to situations, because it was observed that a proportion of the Grin $1^{D 481 N / K 483 Q}$ group would jump off the rotarod repeatedly. In addition, the $\operatorname{Grin} 1^{D 481 N / K 483 Q}$ mice showed increased reactivity to noise and were startled easily. The body posture of 5 of 14 Grin1 $1^{D 481 N / K 483 Q}$ mice differed from wild-type in that they had a raised abdomen. Eight of 14 Grin $1^{D 481 N / K 483 Q}$ mice also were observed to have self-inflicted wounds, such as scratched and swollen eyes and ears. As a consequence, some of the Grin1 $1^{D 481 N / K 483 Q}$ mice were killed over the course of this study; accordingly, the group size differs in the following experiments. A second group of Grin $1^{D 481 N / K 483 Q}$ mice was assessed weekly from the age of 9 to 24 weeks; it was noted that, although their weight increased over this period $\left(F_{(11,11)}=\right.$ 59.5; $p<0.0001)$, it was always significantly less than that of the wild-type group $\left(F_{(1,31)}=37.4 ; p<0.0001\right)$ (Fig. $\left.3 A\right)$. Furthermore, the Grin $1^{D 481 N / K 483 Q}$ mice also were impaired on grip strength and rotarod throughout the testing period (assessed every 2 weeks) compared with wild-type mice (data not shown).

\section{Spontaneous locomotor activity}

Grin $1^{D 481 N / K 483 Q}$ mice were significantly more active than wildtype mice $\left(F_{(1,26)}=24.2 ; p<0.0001\right)$ and did not habituate to the chambers during the test period (Group $\times$ Time bin interaction: $\left.F_{(11,286)}=10.1 ; p<0.0001\right)$ (Fig. $\left.3 B\right)$. Total mobile counts $(t=$ $-4.9 ; p<0.0001)$ in the $1 \mathrm{hr}$ period were significantly higher in the Grin $1^{D 481 N / K 483 Q}$ group compared with the wild-type group (Fig. 3B, inset). This hyperactivity persisted across repeated testing. A second group of $\operatorname{Grin} 1^{D 481 N / K 483 Q}$ mice was tested in the same activity chambers every 2 weeks for a $1 \mathrm{hr}$ period from the age of 9 to 24 weeks (data not shown), and the total distance was increased significantly compared with the wild-type group on every test day.

\section{Nest building}

Figure $3 C$ shows two photographs of a representative mouse from each group: a wild-type mouse with a complete nest and a Grin $1^{D 481 N / K 483 Q}$ mouse without a nest. At $24 \mathrm{hr}$ after the introduction of nesting material all of the wild-type mice had built an adequate nest characterized by the mice sitting within a mound of shredded tissue, whereas only one of eight Grin $1^{D 481 N / K 483 Q}$ mice had built a nest (Fig. $3 C$ ). In the remainder of cases the tissue paper mainly was untouched by the mutant mice.

\section{Twenty-four hour locomotor activity}

The Grin $1^{D 481 N / K 483 Q}$ mice had a normal circadian rhythm, i.e., their activity reduced during the light phase and then markedly increased at the beginning of the dark phase (Fig. 3D). However, Grin $1^{D 481 N / K 483 Q}$ mice were more active than wild-type mice throughout the $24 \mathrm{hr}$ test period in both the distance traveled $\left(F_{(23,23)}=6.9 ; p<0.0001\right)$ and the number of stereotypy counts 
A

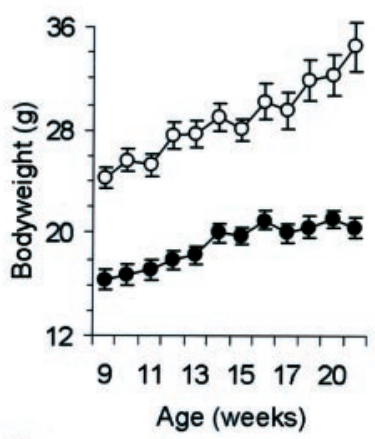

B

C
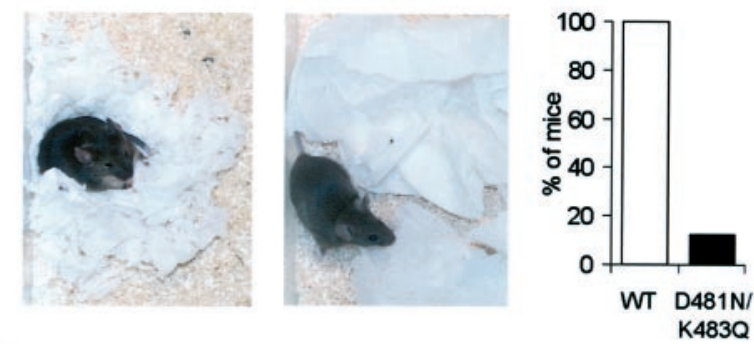

D
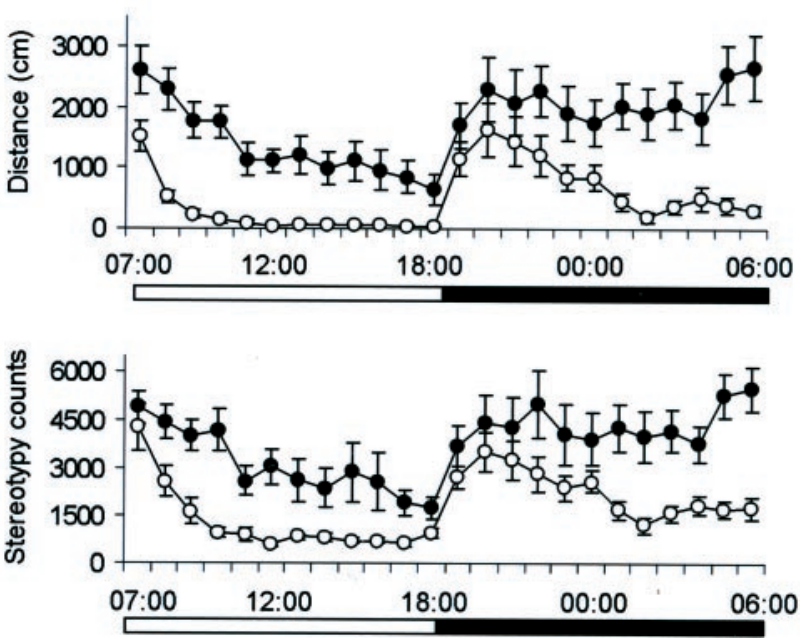

Figure 3. $A$, The mean weight (gm) $\pm \mathrm{SE}$ of wild-type (open circles, $n=$ 20 ) and Grin $1^{D 481 N / K 483 Q}$ ( filled circles, $n=13$ ) mice over weekly testing periods. $B$, Spontaneous locomotor activity (mean mobile counts $\pm \mathrm{SE}$ ) in novel activity cages of wild-type (open circles, $n=14$ ) and Grin $1^{\text {D481N/ }}$ $K 483 Q$ ( filled circles, $n=14$ ) mice. The data are presented in 5 min time bins over a $1 \mathrm{hr}$ period; the inset represents the total activity in $1 \mathrm{hr}$ (unpaired $t$ test; ${ }^{* *} p<0.01$ vs wild-type). $C$, Photographs of representative nests built by a wild-type mouse (left) and a Grin $1^{D 481 N / K 483 Q}$ mouse (right). The bar graph represents the percentage of mice with completed nests $24 \mathrm{hr}$ after the placement of a folded tissue in the home cage. $D$, Distance traveled (in centimeters) and stereotypy counts of wild-type (open circles, $n=12$ ) and Grin $1^{D 481 N / K 483 Q}$ ( filled circles, $n=12$ ) mice expressed as means \pm SE per hour over a $24 \mathrm{hr}$ period. The white bar below the $x$-axis represents the light phase (6:00 A.M. to 6:00 P.M.), and the black bar represents the dark phase (6:00 P.M. to 6:00 A.M.) of testing.

$\left(F_{(23,23)}=6.9 ; p<0.0001\right)$. The Grin1 $1^{D 481 N / K 483 Q}$ mice did not habituate to their surroundings completely, as indicated by the distance traveled (Group $\times$ Time bin interaction: $F_{(23,506)}=1.6$; $p<0.05)$.

\section{Locomotor activity: drug studies}

Because the Grin1 $1^{D 481 N / K 483 Q}$ mice were significantly hyperactive, even on repeated testing, compounds from different pharmacological classes were tested to determine whether this behavior could be modified. The compounds that were selected included two psychostimulant drugs, dizocilpine and amphetamine; the "atypical" antipsychotic, clozapine; the "typical" antipsychotic, haloperidol; the 5-HT2A receptor antagonist, M100907 (Kehne et al., 1996); and the benzodiazepine $\alpha 1$ subunit-selective agonist, Zolpidem (Graham et al., 1996). M100907 was selected given accumulating evidence that 5-HT2A receptor antagonists can normalize certain behaviors related to reduced NMDA function (Maurel-Remy et al., 1995; Varty and Higgins, 1995; Carlsson et al., 1999) and Zolpidem because its potent sedative properties are not mediated directly via dopaminergic, serotonergic, or glutamatergic mechanisms (Crestani et al., 2000).

\section{Dizocilpine}

Dizocilpine significantly increased the total distance traveled $\left(F_{(2,22)}=47.8 ; p<0.0001\right)$ in the wild-type group at $0.3 \mathrm{mg} / \mathrm{kg}$ $(p<0.001)$, whereas there was not a significant increase in activity in the $G \operatorname{rin} 1^{D 481 N / K 483 Q}$ mice $\left(F_{(2,12)}=0.4 ; p=0.7\right)$ (Fig. $4 A$ ). This was supported by a significant Genotype $\times$ Dose interaction $\left(F_{(2,34)}=20.1 ; p<0.0001\right)$. Dizocilpine significantly increased stereotypy counts $\left(F_{(2,22)}=24.4 ; p<0.0001\right)$ in the wildtype group at $0.3 \mathrm{mg} / \mathrm{kg}(p<0.001)$ but did not increase activity in the Grin1 $1^{D 481 N / K 483 Q}$ mice, as shown by a significant Genotype $\times$ Dose interaction $\left(F_{(2,12)}=16.6 ; p<0.0001\right)$ (Fig. $\left.4 B\right)$.

\section{Amphetamine}

Amphetamine significantly increased the distance traveled $\left(F_{(3,30)}=44.4 ; p<0.0001\right)$ in the wild-type group at $1 \mathrm{mg} / \mathrm{kg}$ $(p<0.01)$ and $3 \mathrm{mg} / \mathrm{kg}(p<0.0001)$. There was also a significant increase in total distance in the Grin $1^{D 481 N / K 483 Q}$ mice $\left(F_{(3,12)}=\right.$ 10.4; $p<0.01$ ) after $3 \mathrm{mg} / \mathrm{kg}$ amphetamine $(p<0.001)$ (Fig. $4 C$ ). This was supported by a main effect of dose $\left(F_{(3,3)}=32.6 ; p<\right.$ 0.0001). Amphetamine also significantly increased stereotypy counts $\left(F_{(3,30)}=66.9 ; p<0.0001\right)$ in the wild-type group at 1 $\mathrm{mg} / \mathrm{kg}(p<0.01)$ and $3 \mathrm{mg} / \mathrm{kg}(p<0.0001)$. There was a significant effect $\left(F_{(3,12)}=7.7 ; p<0.01\right)$ of amphetamine on stereotypy counts in the Grin $1^{D 481 N / K 483 Q}$ mice at $3 \mathrm{mg} / \mathrm{kg}$ $(p<0.05)($ Fig. $4 D)$. This is supported by a main effect of dose $\left(F_{(3,3)}=46.4 ; p<0.0001\right)$.

\section{Clozapine}

Clozapine significantly reduced the distance traveled $\left(F_{(3,36)}=\right.$ $19.3 ; p<0.0001)$ in the wild-type group at $0.3 \mathrm{mg} / \mathrm{kg}(p<0.01)$ and $1 \mathrm{mg} / \mathrm{kg}(p<0.0001)$. There was not a significant effect of clozapine on total distance in the Grin $1^{D 481 N / K 483 Q}$ mice $\left(F_{(3,27)}=1.9 ; p=0.2\right)$ (Fig. $\left.5 A\right)$. Clozapine also significantly decreased stereotypy counts $\left(F_{(3,36)}=24.9 ; p<0.0001\right)$ in the wild-type group at $0.1 \mathrm{mg} / \mathrm{kg}(p<0.01), 0.3 \mathrm{mg} / \mathrm{kg}(p<0.001)$, and $1 \mathrm{mg} / \mathrm{kg}(p<0.0001)$. There was also a significant effect $\left(F_{(3,27)}=5.01 ; p<0.01\right)$ of clozapine on stereotypy counts in the Grin1 $^{D 481 N / K 483 Q}$ mice at $1 \mathrm{mg} / \mathrm{kg}(p<0.01)$ (Fig. $\left.5 B\right)$.

\section{Haloperidol}

Haloperidol significantly reduced the distance traveled $\left(F_{(3,27)}=\right.$ $11.4 ; p<0.0001)$ in the wild-type group at $0.1 \mathrm{mg} / \mathrm{kg}(p<0.05)$ and $0.3 \mathrm{mg} / \mathrm{kg}(p<0.01)$. There was not a significant effect of haloperidol on total distance in the Grin1 $1^{D 481 N / K 483 Q}$ mice 

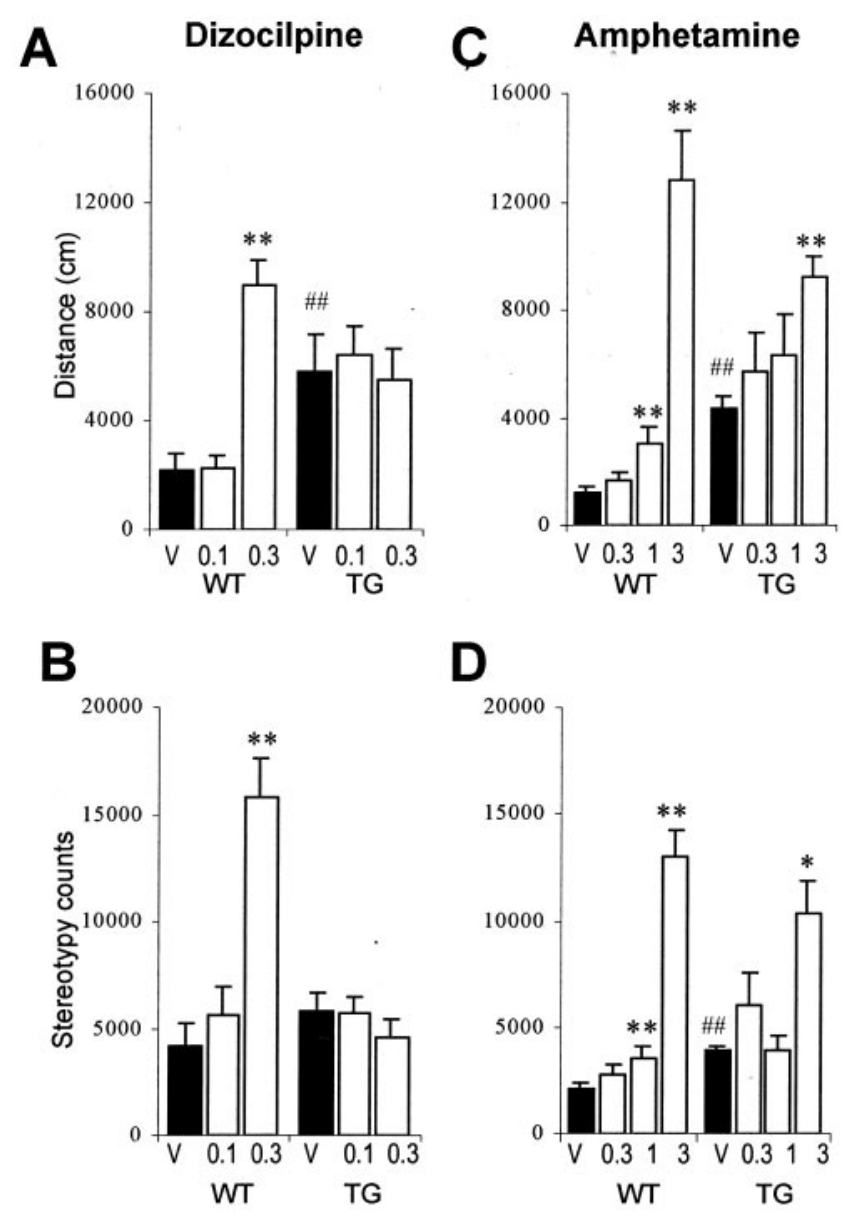

Figure 4. Effect of dizocilpine $(0.1,0.3 \mathrm{mg} / \mathrm{kg})$ in wild-type $(n=12)$ and Grin1 $1^{D 481 N / K 483 Q}(n=7)$ mice on the total distance (in centimeters) traveled $(A)$ and stereotypy counts $(B)$ in a $90 \mathrm{~min}$ period. Effect of amphetamine $(0.3,1,3 \mathrm{mg} / \mathrm{kg})$ in wild-type $(n=11)$ and $G r i n 1^{D 481 N / K 483 Q}$ $(n=5)$ mice on the total distance (in centimeters) traveled $(C)$ and stereotypy counts $(D)$ in a $1 \mathrm{hr}$ period. Data are expressed as means $\pm \mathrm{SE}$; repeated measures design. ${ }^{*} p<0.05,{ }^{*} p<0.01$ dose versus respective vehicle group; ${ }^{\#} p<0.05,{ }^{\# \#} p<0.01$ Grin1 ${ }^{D 481 N / K 483 Q}$ versus wild type (vehicle-treated). WT, Wild-type mice; TG, Grin $1^{D 481 N / K 483 Q}$ mice.

$\left(F_{(3,15)}=1.4 ; p=0.3\right)$ (Fig. $\left.5 C\right)$. Haloperidol significantly decreased stereotypy counts $\left(F_{(3,27)}=12.5 ; p<0.0001\right)$ in the wild-type group at $0.1 \mathrm{mg} / \mathrm{kg}(p<0.05)$ and $0.3 \mathrm{mg} / \mathrm{kg}(p<$ $0.01)$. There was also a significant effect $\left(F_{(3,15)}=6.3 ; p<0.01\right)$ of haloperidol on stereotypy counts in the Grin $1^{D 481 N / K 483 Q}$ mice at $0.3 \mathrm{mg} / \mathrm{kg}(p<0.05)$ (Fig. $5 D)$.

\section{M100907}

M100907 significantly reduced the distance traveled $\left(F_{(3,33)}=\right.$ $15.5 ; p<0.0001)$ in the wild-type group at $0.3 \mathrm{mg} / \mathrm{kg}(p<$ 0.0001). There was not a significant effect of M100907 on total distance in the Grin1 $1^{D 481 N / K 483 Q}$ mice $\left(F_{(3,30)}=0.7 ; p=0.6\right)$ (Fig. $5 E)$. M100907 significantly decreased stereotypy counts $\left(F_{(3,33)}=\right.$ $13.2 ; p<0.0001)$ in the wild-type group at $0.03 \mathrm{mg} / \mathrm{kg}(p<0.05)$ and $0.3 \mathrm{mg} / \mathrm{kg}(p<0.0001)$. There was not a significant effect $\left(F_{(3,30)}=1.2 ; p=0.3\right)$ of M100907 on stereotypy counts in the Grin1 $^{D 481 N / K 483 Q}$ mice (Fig. $5 F$ ).

\section{Zolpidem}

Zolpidem significantly reduced the distance traveled $\left(F_{(2,20)}=\right.$ 26.4; $p<0.0001)$ in the wild-type group at $3 \mathrm{mg} / \mathrm{kg}(p<0.01)$ and $10 \mathrm{mg} / \mathrm{kg}(p<0.001)$. There was not a significant effect of Zolpidem on total distance in the $\operatorname{Grin1} 1^{D 481 N / K 483 Q}$ mice $\left(F_{(2,8)}=\right.$ $0.5 ; p=0.6$ ) (Fig. 5G). Zolpidem significantly decreased stereotypy counts $\left(F_{(2,20)}=69.6 ; p<0.0001\right)$ in the wild-type group at $3 \mathrm{mg} / \mathrm{kg}(p<0.0001)$ and $10 \mathrm{mg} / \mathrm{kg}(p<0.0001)$. There was not a significant effect $\left(F_{(2,8)}=0.08 ; p=0.9\right)$ of Zolpidem on stereotypy counts in the Grin1 $1^{D 481 N / K 483 Q}$ mice (Fig. $5 H$ ).

\section{Prepulse inhibition}

The Grin $1^{D 481 N / K 483 Q}$ mice had exaggerated startle reactivity at 82, 90, and $110 \mathrm{~dB}\left(F_{(4,104)}=14.9 ; p<0.0001\right)$ (Fig. $\left.6 A\right)$ but normal PPI $\left(F_{(2,52)}=1.1 ; p=0.3\right)$ compared with the wild-type mice (Fig. $6 B$ ). Under a second protocol the startle reactivity again was increased significantly in $\operatorname{Grin} 1^{D 481 N / K 483 Q}$ mice compared with wild-type mice (data not shown). There was a small reduction in PPI in the Grin $1^{D 481 N / K 483 Q}$ group compared with the wild-type group, with an interstimulus interval of $30 \mathrm{msec}$ (Fig. 6C). However, there was not an interaction between genotype and interval $\left(F_{(2,52)}=0.6 ; p=0.6\right)$, and this effect may be attributable to interference from the increased startle response by the Grin $1^{D 481 N / K 483 Q}$ mice to the prepulse with this short prepulse-pulse interval.

\section{Water maze: cued acquisition}

Previous work has demonstrated that homozygous Grin $1^{D 481 N}$ mice are mildly impaired on a spatial learning task (Kew et al., $2000)$; therefore, we decided to assess the Grin $1^{D 481 N / K 483 Q}$ mice in a water maze task. Because of the neurological deficits noted with these mice, they were trained initially on a cued task (visible platform) to ensure that they were able to locate and climb onto a platform before the spatial learning task. The wild-type group learned to find a visible platform across the testing sessions, as indicated by a significant reduction in path length $\left(F_{(3,3)}=11.0\right.$; $p<0.0001)$. However, the Grin1 $1^{D 481 N / K 483 Q}$ mice failed to learn to find a visible platform in the water maze across the sessions $\left(\right.$ Genotype $\times$ Session: $\left.F_{(3,48)}=6.0 ; p<0.01\right)($ Fig. $7 A)$. Figure $7 B$ represents the swim paths of a mouse from the wild-type group, showing that by the third session the mouse swam directly toward the platform. The Grin1 $1^{D 481 N / K 483 Q}$ mice never found the platform during testing. When placed into the maze, the mice swam quickly and erratically, often in circles with no clear search strategy (Fig. $7 C$ ). Most of the mice had difficulty in swimming (one mouse had to be removed because it was unable to swim), and, when placed onto the platform, the mice would jump off repeatedly, similar to the behavior noted with some mice on the rotarod. Because the mice were unable to learn this cued task, no further water maze testing was undertaken.

\section{DISCUSSION}

We have reported previously that homozygous $G r i n 1^{D 481 N}$ mice, exhibiting a fivefold reduction in NMDA receptor glycine affinity, survive to adulthood, whereas homozygous Grin $1^{K 483 Q}$ animals do not feed and die within a few days of birth (Kew et al., 2000). In this study we have characterized compound heterozygous Grin $1^{D 481 N / K 483 Q}$ mice. These mice are viable and exhibit biphasic NMDA receptor glycine concentration-response curves compatible with the presence of each of the two mutated NMDAR1 subunits, although receptor glutamate affinity is unchanged.

The high- and low-affinity components of the biphasic glycine concentration-response curves obtained from the Grin $1^{D 481 N / K 483 Q}$ mice are in good agreement with those of the monophasic curves previously determined in homozygous 

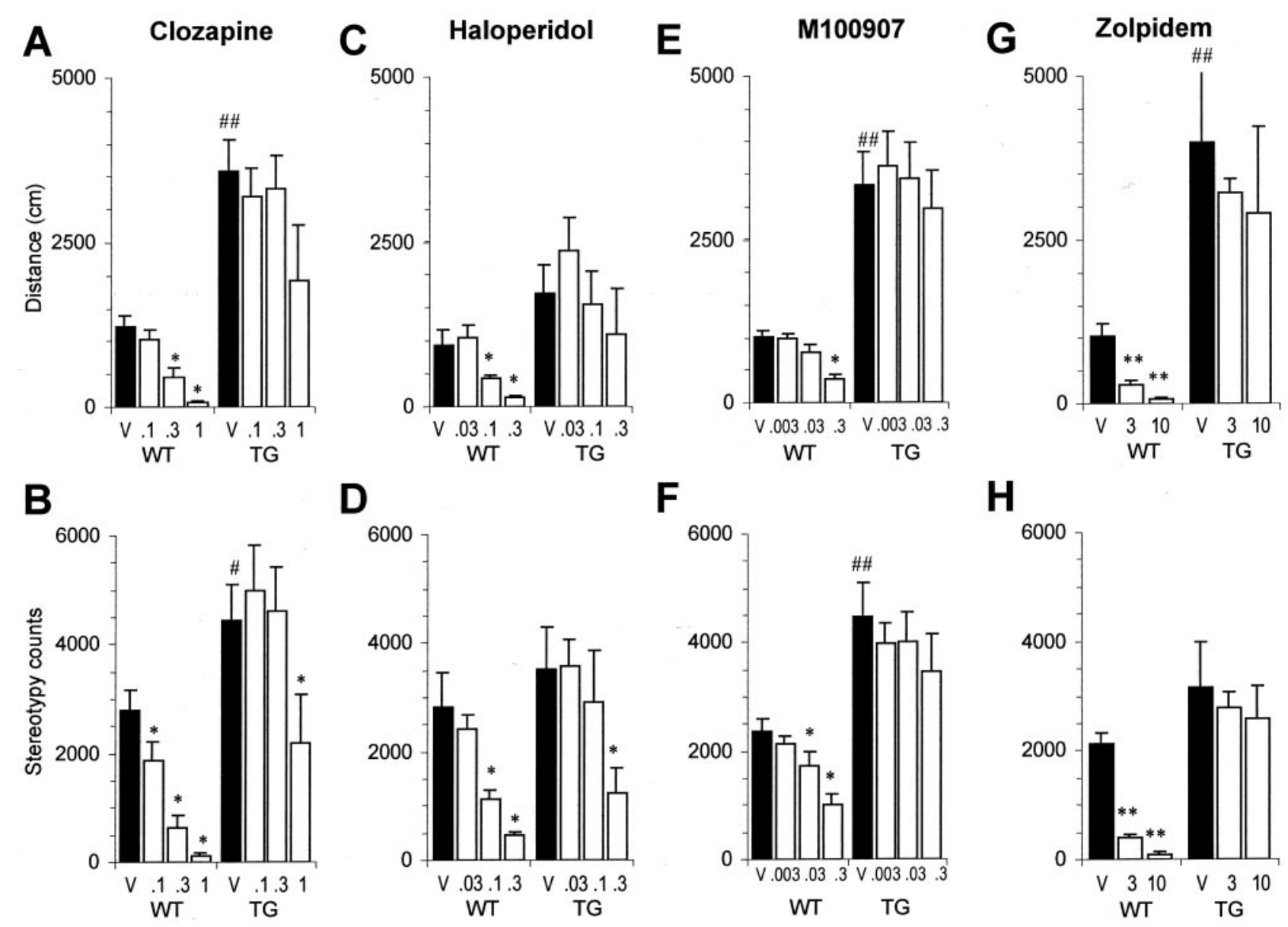

Figure 5. Effect of clozapine $(0.1,0.3,3 \mathrm{mg} / \mathrm{kg})$ in wild-type $(n=13)$ and $\operatorname{Grin} 1^{D 481 N / K 483 Q}(n=12)$ mice on the total distance (in centimeters) traveled $(A)$ and stereotypy counts $(B)$ in a $1 \mathrm{hr}$ period. Effect of haloperidol $(0.03,0.1,0.3 \mathrm{mg} / \mathrm{kg})$ in wild-type $(n=10)$ and $\mathrm{Grin} 1^{D 481 N / K 483 Q}(n=6)$ mice on the total distance (in centimeters) traveled $(C)$ and stereotypy counts $(D)$ in a $1 \mathrm{hr}$ period. Effect of M100907 $(0.003,0.03,0.3 \mathrm{mg} / \mathrm{kg})$ in wild-type $(n=$ $12)$ and Grin1 ${ }^{D 481 N / K 483 Q}(n=11)$ mice on the total distance (in centimeters) traveled $(E)$ and stereotypy counts $(F)$ in a $1 \mathrm{hr}$ period. Effect of Zolpidem $(3,10 \mathrm{mg} / \mathrm{kg})$ in wild-type $(n=11)$ and $\operatorname{Grin1} 1^{D 481 N / K 483 Q}(n=5)$ mice on the total distance (in centimeters) traveled $(G)$ and stereotypy counts $(H)$ in a $1 \mathrm{hr}$ period. Data are expressed as means $\pm \mathrm{SE}$; repeated measures design. ${ }^{*} p<0.05,{ }^{*} p<0.01$ dose versus respective vehicle group; $\# p<0.05$, $\# \# p<0.01$ Grin1 $1^{D 481 N / K 483 Q}$ versus wild type (vehicle-treated). WT, Wild-type mice; TG, Grin1 $1^{D 481 N / K 483 Q}$ mice.

Grin1 $1^{D 481 N}$ and Grin1 $1^{K 483 Q}$ animals, respectively (Kew et al., 2000). Interestingly, no intermediate affinities were observed. The proportions of the high- and low-affinity components that were observed (16 and $84 \%$, respectively) are compatible with a tetrameric receptor stoichiometry of two NMDAR1 and two NR2 subunits (Laube et al., 1998), subject to a number of assumptions. These include the equal expression and random assembly of the two mutated NMDAR1 subunits, the independence of the two glycine binding sites (which is supported by the absence of any discernible intermediate glycine affinities), and the determination of the net receptor glycine affinity by the lower affinity of the two obligatory glycine binding sites. With these assumptions in place, any receptor containing a Grin1 $1^{K 483 Q}$ NMDAR1 subunit must exhibit a low affinity; thus only receptors containing two Grin $1^{D 481 N}$ subunits can exhibit a high affinity so that for an NMDA receptor population of tetramers containing two NMDAR1 and two NR2 subunits, a 25\% high-affinity, $75 \%$ low-affinity distribution would be predicted. This prediction is similar to the ratios that have been determined experimentally. Saturation binding analysis with $\left[{ }^{3} \mathrm{H}\right]$-dizocilpine in the presence of saturating glutamate and glycine revealed no differences in $K_{\mathrm{D}}$ or $B_{\max }$ between wild-type and Grin1 $1^{D 481 N / K 483 Q}$ mice, demon- strating that the number of functional membrane receptors does not differ between wild-type and mutant animals.

The behavioral changes we have reported previously in Grin $1^{D 481 N}$ homozygous animals were apparent even with a relatively small (fivefold) reduction in receptor glycine affinity, suggesting that the ambient glycine affinity in wild-type animals is not far above threshold (Kew et al., 2000). Because the large majority of NMDA receptors in Grin1 $1^{D 481 N / K 483 Q}$ mice appears to exhibit an $\sim 90$-fold reduction in glycine affinity as revealed by concentration-response analysis, it is likely that, in the absence of any compensatory mechanism, a far larger proportion of NMDA receptors will not be functional in these compound heterozygote animals. Both population NMDA receptor responses assayed by using a greased gap cortical wedge preparation and NMDA receptor EPSCs were potentiated significantly by D-serine in slices from mutant, but not wild-type, animals, illustrating that a significant proportion of NMDA receptors is nonfunctional because of the presence of limiting concentrations of endogenous glycine site ligands. The impact of this reduction in functional NMDA receptors on receptor-dependent signaling was illustrated by the large deficit in LTP induction observed in hippocampal slices from Grin $1^{D 481 N / K 483 Q}$ mice, which was rescued 
A

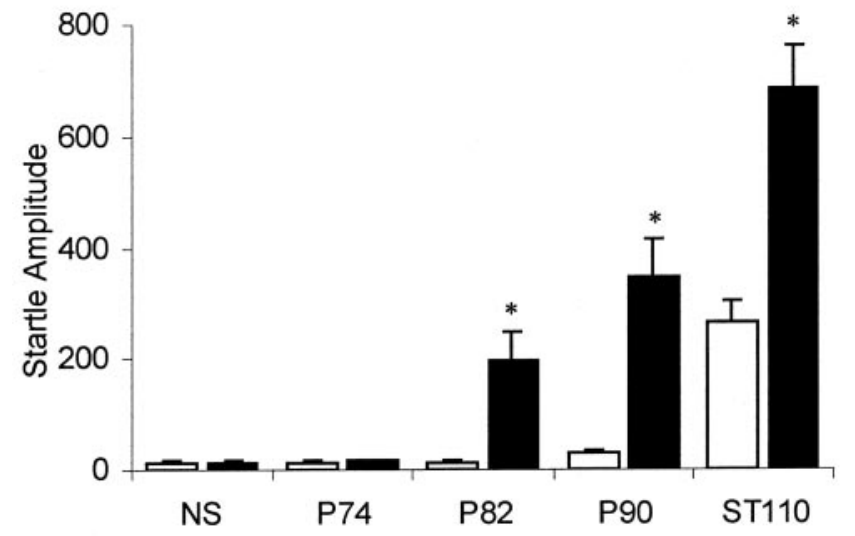

B

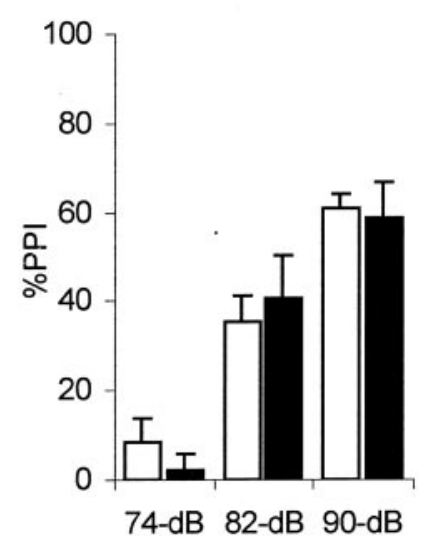

C

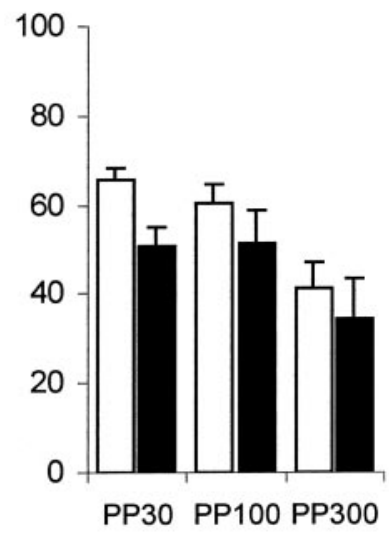

Figure 6. A, Startle amplitude (means $\pm \mathrm{SE}$ ) of wild-type (white bar) and Grin1 ${ }^{\text {D481N/K483Q }}$ (black bar) after no stimulus $(N S)$; shown are pulses of 74, 82, and $90 \mathrm{~dB}(P 74, P 82, P 90)$ and stimulus threshold of $110 \mathrm{~dB}$ (ST110). B, Percentage of prepulse inhibition at prepulses of 74,82 , and $90 \mathrm{~dB}$, followed by a $110 \mathrm{~dB}$ pulse. $C$, Percentage of prepulse inhibition at prepulse $(90 \mathrm{~dB})$, followed by a pulse $(110 \mathrm{~dB})$ after different interstimulus intervals of 30,100 , and $300 \mathrm{msec}$. Data are expressed as means $\pm \mathrm{SE}$; ${ }^{*} p<0.05$ versus respective wild-type group.

by the addition of D-serine $(100 \mu \mathrm{M})$. PTP remained somewhat attenuated in mutant animals in the presence of D-serine, which is a full agonist at the NMDA receptor glycine site with a similar affinity to glycine (Priestley et al., 1995). Thus the PTP and LTP phases of potentiation might be differentially dependent on the extent of NMDA receptor activation. NR2A-containing NMDA receptors, which are expressed together with NR2B in hippocampal slices from mature mice (Kew et al., 1998), exhibit an $\sim 10$ fold reduction in glycine affinity relative to those containing NR2B as the sole NR2 subunit (Kutsuwada et al., 1992; Priestley et al., 1995; Kew et al., 1998). Thus in adult Grin1 $1^{\text {481N/K483Q }}$ animals the saturating glycine concentration is likely to be in the millimolar range, as suggested by our cortical wedge data, somewhat higher than that we observed in our concentration-response analysis, using neurons from 7 to 12 animals in which NR2B is likely to be the predominant NR2 subunit. The absence of the facilitatory effect of D-serine on NMDA receptor-mediated activity in all brain slices from wild-type animals also suggests that under our experimental conditions the glycine site agonist con-

A
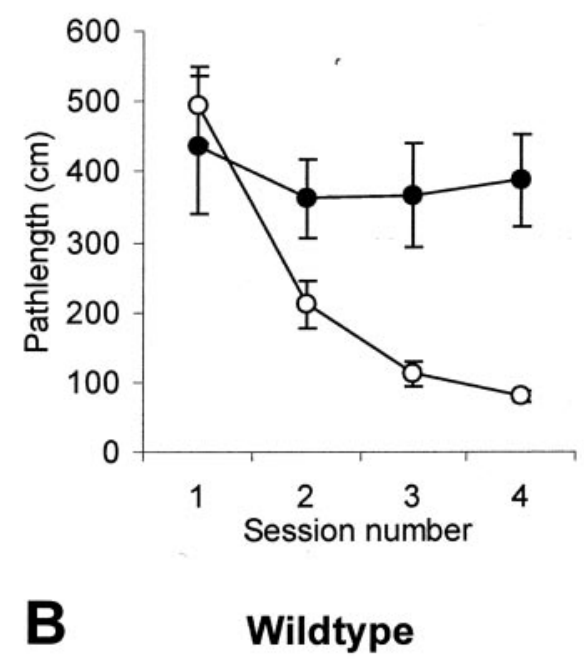

1.

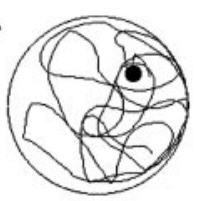

2.

3.
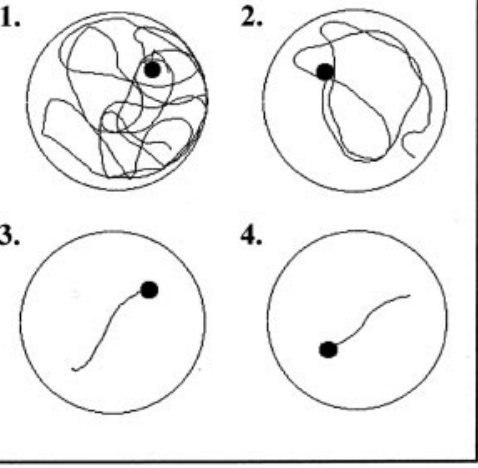

C Grin1 ${ }^{D 481 N / K 483 Q}$

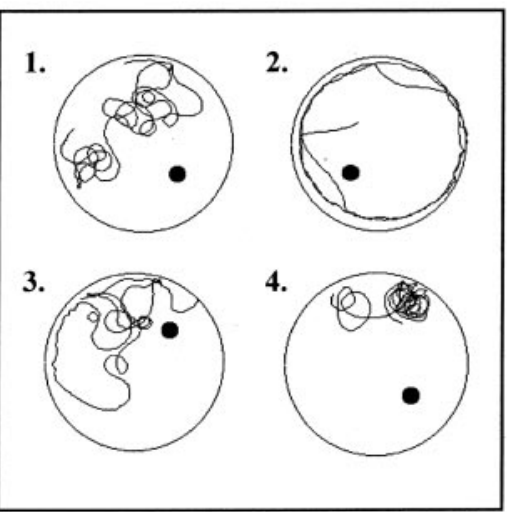

Figure 7. A, Path length (in centimeters) traveled to find a visible cued platform in the water maze (means of 3 trials \pm SE) per session (two sessions per day) by wild-type (open circles, $n=10$ ) and Grin $1^{D 481 N / K 483 Q}$ mice ( filled circles, $n=8$ ). $B$, Swim paths of a representative wild-type mouse (one trial from each session). $C$, Swim paths of representative Grin1 $1^{D 481 N / K 483 Q}$ mouse (one trial from each session).

centration at NMDA receptors in these slices is at, or close to, saturating levels.

The most striking behavioral phenotype of the Grin1 $1^{D 481 N / K 483 Q}$ mice was hyperactivity, which persisted over repeated testing and 
was evident over a $24 \mathrm{hr}$ period, although some circadian pattern was evident. There was also a significant increase in stereotypy counts recorded in these experiments, which through visual inspection suggested a relationship with excessive grooming and scratching in the mutants. Indeed, the severity of this behavior was such that over the course of these studies many of the Grin1 $1^{D 481 N / K 483 Q}$ mice developed self-inflicted facial lesions, resulting in the loss of some animals because of health considerations. Grin $1^{D 481 N / K 483 Q}$ mice also were impaired in nest building, suggesting further disruption to normal home cage behaviors.

During the neurological assessment it was noted that the Grin $1^{D 481 N / K 483 Q}$ mice were hyper-reactive to noise. This was assessed formally in PPI tests. The Grin1 $1^{D 481 N / K 483 Q}$ mice had a significantly increased startle response compared with controls, with a startle threshold at $82 \mathrm{~dB}$. Homozygous mutant Grin $1^{D 481 N}$ mice also show increased startle reactivity, with a threshold startle at $90 \mathrm{~dB}$ (Kew et al., 2000). This indicates that the increased startle response is dependent on the degree of reduction in receptor glycine affinity. There was no PPI difference between the wild-type and Grin $1^{D 481 N / K 483 Q}$ group, which is also consistent with the homozygous Grin $1^{D 481 N}$ mice (Kew et al., 2000).

Given the robust hyperactivity seen in the Grin $1^{D 481 N / K 483 Q}$ mice, we focused drug interaction studies on this aspect of behavior. Dizocilpine elicited a significant increase in locomotor and stereotypy counts in wild-type, but not Grin1 $1^{D 481 N / K 483 Q}$, mice, thus providing in vivo confirmation of reduced NMDA receptor tone in the Grin $1^{D 481 N / K 483 Q}$ mice. Interestingly, even if we take into account the baseline phenotypic differences, the magnitude of amphetamine effect on activity and stereotypy measures was similar. This indicates that the null effect of dizocilpine pretreatment on motor function in Grin1 $1^{D 481 N / K 483 Q}$ mice is not attributable to a ceiling effect.

Clozapine did not affect the activity of the Grin1 $1^{D 481 N / K 483 Q}$ mice across a dose range that significantly reduced locomotion and stereotypy counts in the wild-type mice. Only at the highest dose that was tested $(1 \mathrm{mg} / \mathrm{kg})$ was there a slight, nonsignificant, reduction in the distance traveled and a significant reduction in stereotypy counts in the Grin $1^{D 481 N / K 483 Q}$ mice. Haloperidol, M100907, and Zolpidem, in particular, also exerted relatively little effect on activity or stereotypy measures of Grin $1^{D 481 N / K 483 Q}$ compared with the wild-type mice. Taken together, the results clearly show that the hyperlocomotor phenotype of Grin $1^{D 481 N / K 483 Q}$ mice is resistant to pharmacological suppression.

It is of interest to note that, unlike channel blockers (e.g., PCP and dizocilpine), NMDA receptor glycine site antagonists such as L-701,324 produce little or no stimulation of locomotor activity at anti-convulsant doses in mice (Bristow et al., 1996), with pronounced ataxia evident at higher doses. However, L-687,414, a low-efficacy partial agonist, exhibited stimulant activity at high doses (Tricklebank et al., 1994). The reason for these discrepancies is unclear but might relate to the rate of block of NMDA receptors. Full glycine site antagonists of the L-701,324 class penetrate the CNS quite poorly when compared with PCP, dizocilpine, or L-687,414, and studies with competitive glutamate site antagonists indicate that rapid intravenous dosing induces more severe side effects than drug administration by routes with slower rates of adsorption (Lowe et al., 1994).

Nevertheless, in multiple studies with rodents the reduction of NMDA receptor activity either pharmacologically or genetically has been reported to result in behaviors including hyperactivity, increased stereotypy, and deficits in social interaction together with the alteration of monoaminergic systems, and many of these changes can be attenuated by antipsychotic drugs (Hiramatsu et al., 1989; Corbett et al., 1995; Mohn et al., 1999; Miyamoto et al., 2001). Accordingly, these strategies have been adopted to model schizophrenia. Grin $1^{D 481 N / K 483 Q}$ mice exhibited a phenotype with similarities to other mice with genetically reduced NMDA receptor function. However, in contrast to the previous studies the hyperactivity exhibited by $\operatorname{Gin} 1^{D 481 N / K 483 Q}$ mice was not attenuated by antipsychotic drugs at concentrations that were without effect in wild-type animals (Mohn et al., 1999; Miyamoto et al., 2001). Moreover, even exposure to higher levels of antipsychotic drugs that were markedly sedative in wild-type animals did not reduce the hyperlocomotion and only partially attenuated the increased stereotypy of Grin1 $1^{D 481 N / K 483 Q}$ mice. Grin $1^{D 481 N / K 483 Q}$ mice also were distinguished by the sustained, nonhabituating nature of the observed hyperactivity. It is possible that the apparently more severe phenotype observed with Grin $1^{D 481 N / K 483 Q}$ mice reflects a relatively larger deficit in NMDA receptor function compared with the NR2A knock-out (Miyamoto et al., 2001) and NR1 "knock-down" mice (Mohn et al., 1999). In agreement, the severity of the phenotype prevented the inclusion of cognitive tests such as spatial water maze learning, previously performed with NR2A knock-outs (Sakimura et al., 1995). A further distinction is that $\operatorname{Grin} 1^{D 481 N / K 483 Q}$ mice exhibit reduced NMDA receptor function while retaining a full receptor complement, whereas the NR2A knock-out and NR1 knock-down mice both exhibit significant reductions in the absolute number of receptors (Mohn et al., 1999; Miyamoto et al., 2001). Such a marked loss of a major component of postsynaptic density may result in compensatory changes that could contribute to their phenotype.

The lack of effect of the benzodiazepine agonist Zolpidem on the hyperactivity of the Grin $1^{D 481 N / K 483 Q}$ mice is of potential interest. This may reflect a reduction of GABAergic tone in these mice, i.e., a disinhibition, which would be compatible with the observed hyperactivity and excessive stereotypy. Indeed, GABAergic dysfunction has been proposed as a contributing factor to the pathophysiology of schizophrenia (Lewis and Lieberman, 2000; Carlsson et al., 2001). Disinhibition as a result of NMDA receptor hypof unction has emerged as a core principle of the NMDA receptor model of schizophrenia proposed by Olney et al. (1999). The severity of NMDA receptor hypofunction in $G r i n 1^{D 481 N / K 483 Q}$ mice may render these mice of limited value as models of this disease, at least in terms of response to pharmacological challenge. Nonetheless, the potential for a more subtle disruption of NMDA function via the generation of heterozygous Grin $1^{K 483 Q}$ or heterozygous and homozygous Grin $1^{D 481 N}$ mice might yield improved models for studying diseases related to NMDA receptor hypofunction such as schizophrenia.

\section{REFERENCES}

Anson LC, Chen PE, Wyllie DJA, Colquhoun D, Schoepfer R (1998) Identification of amino acid residues of the NR2A subunit that control glutamate potency in recombinant NR1/NR2A NMDA receptors. J Neurosci 18:581-589.

Benveniste M, Mayer ML (1991) Kinetic analysis of antagonist action at $N$-methyl-D-aspartic acid receptors. Biophys J 59:560-573.

Bristow LJ, Hutson PH, Kulagowski JJ, Leeson PD, Matheson S, Murray F, Rathbone D, Saywell KL, Thorn L, Watt AP, Tricklebank MD (1996) Anticonvulsant and behavioural profile of L-701,324, a potent, orally active antagonist at the glycine modulatory site on the $N$-methylD-aspartate receptor complex. J Pharmacol Exp Ther 279:492-501.

Carlsson A, Waters N, Holm-Waters S, Tedroff J, Nilsson M, Carlsson ML (2001) Interactions between monoamines, glutamate, and GABA in schizophrenia: new evidence. Annu Rev Pharmacol Toxicol 41:237-260.

Carlsson ML, Martin P, Nilsson M, Sorensen SM, Carlsson A, Waters S, 
Waters N (1999) The 5-HT2A receptor antagonist M100907 is more effective in countering NMDA antagonist- than dopamine agonistinduced hyperactivity in mice. J Neural Transm 106:123-129.

Clements JD, Westbrook GL (1991) Activation kinetics reveal the number of glutamate and glycine binding sites on the $N$-methyl-D-aspartate receptor. Neuron 7:605-613.

Corbett R, Camacho F, Woods AT, Kerman LL, Fishkin RJ, Brooks K, Dunn RW (1995) Antipsychotic agents antagonize noncompetitive $N$-methyl-D-aspartate antagonist-induced behaviours. Psychopharmacology 120:67-74.

Crestani F, Martin JR, Möhler H, Rudolf U (2000) Mechanism of action of the hypnotic Zolpidem in vivo. Br J Pharmacol 131:1251-1254.

Da Prada M, Kettler R, Keller HH, Burkard WP, Muggli-Maniglio D, Haefely WE (1989) Neurochemical profile of moclobemide, a shortacting and reversible inhibitor of monoamine oxidase type A. J Pharmacol Exp Ther 248:400-414.

Forrest D, Yuzaki M, Soares HD, Ng L, Luk DC, Sheng M, Stewart CL, Morgan JI, Connor JA, Curran T (1994) Targeted disruption of the NMDA receptor 1 gene abolishes NMDA response and results in neonatal death. Neuron 13:325-338.

Geyer MA, Krebs-Thomson K, Braff DL, Swerdlow NR (2001) Pharmacological studies of prepulse inhibition models of sensorimotor gating deficits in schizophrenia: a decade in review. Psychopharmacology 156:117-154.

Graham D, Faure C, Besnard F, Langer SZ (1996) Pharmacological profile of benzodiazepine site ligands with recombinant $\mathrm{GABA}_{\mathrm{A}}$ receptor subtypes. Eur Neuropsychopharmacol 6:119-125.

Higgins GA, Grottick AJ, Ballard TM, Richards JG, Messer J, Takashima H, Pauly-Evers M, Jenck F, Adam G, Wichmann J (2001) Influence of the selective ORL1 receptor agonist, Ro64-6198, on rodent neurological function. Neuropharmacology 41:97-107.

Hirai H, Kirsch J, Laube B, Betz H, Kuhse J (1996) The glycine binding site of the $N$-methyl-D-aspartate receptor subunit NR1: identification of novel determinants of coagonist potentiation in the extracellular M3-M4 loop region. Proc Natl Acad Sci USA 93:6031-6036.

Hiramatsu M, Cho AK, Nabeshima T (1989) Comparison of the behavioural and biochemical effects of the NMDA receptor antagonists, MK801 and phencyclidine. Eur J Pharmacol 166:359-366.

Javitt DC, Zukin SR (1991) Recent advances in the phencyclidine model of schizophrenia. Am J Psychiatry 148:1301-1308.

Johnson JW, Ascher P (1987) Glycine potentiates the NMDA response in cultured mouse brain neurons. Nature 325:529-531.

Kehne JH, Baron BM, Carr AA, Chaney SF, Elands J, Fe DJ, Frank RA, Van Giersbergen PLM, McCloskey TC, Johnson MP, McCarty DR, Poirot M (1996) Preclinical characterization of the potential of the putative atypical antipsychotic MDL 100,907 as a potent $5-\mathrm{HT}_{2 \mathrm{~A}}$ antagonist with a favorable CNS profile. J Pharmacol Exp Ther 277:968-981.

Kew JNC, Richards JG, Mutel V, Kemp JA (1998) Developmental changes in NMDA receptor glycine affinity and ifenprodil sensitivity reveal three distinct populations of NMDA receptors in individual rat cortical neurons. J Neurosci 18:1935-1943.

Kew JNC, Koester A, Moreau J-L, Jenck F, Ouagazzal A-M, Mutel V, Richards JG, Trube G, Fischer G, Montkowski A, Hundt W, Reinscheid RK, Pauly-Evers M, Kemp JA, Bluethmann H (2000) Functional consequences of reduction in NMDA receptor glycine affinity in mice carrying targeted point mutations in the glycine binding site. J Neurosci 20:4037-4049.

Kleckner NW, Dingledine R (1988) Requirement for glycine in activation of NMDA receptors expressed in Xenopus oocytes. Science 241:835-837.

Kuryatov A, Laube B, Betz H, Kuhse J (1994) Mutational analysis of the glycine-binding site of the NMDA receptor: structural similarity with bacterial amino acid-binding proteins. Neuron 12:1291-1300.

Kutsuwada T, Kashiwabuchi N, Mori H, Sakimura K, Kushiya E, Araki K, Meguro H, Masaki H, Kumanishi T, Arakawa M, Mishina M (1992) Molecular diversity of the NMDA receptor channel. Nature 358:36-41.

Kutsuwada T, Sakimura K, Manabe T, Takayama C, Katakura N, Kushiya E, Natsume R, Watanabe M, Inoue Y, Yagi T, Aizawa S, Arakawa M, Takahashi T, Nakamura Y, Mori H, Mishina M (1996) Impairment of suckling response, trigeminal neuronal pattern formation, and hip- pocampal LTD in NMDA receptor $\epsilon 2$ subunit mutant mice. Neuron 16:333-344.

Larson J, Lynch G (1988) Role of $N$-methyl-D-aspartate receptors in the induction of synaptic potentiation by burst stimulation patterned after the hippocampal theta rhythm. Brain Res 441:111-118.

Laube B, Hirai H, Sturgess M, Betz H, Kuhse J (1997) Molecular determinants of agonist discrimination by NMDA receptor subunits: analysis of the glutamate binding site on the NR2B subunit. Neuron 18:493-503.

Laube B, Kuhse J, Betz H (1998) Evidence for a tetrameric structure of recombinant NMDA receptors. J Neurosci 18:2954-2961.

Lewis DA, Lieberman JA (2000) Catching up on schizophrenia: natural history and neurobiology. Neuron 28:325-334.

Li Y, Erzurumlu RS, Chen C, Jhaveri S, Tonegawa S (1994) Whiskerrelated neuronal patterns fail to develop in the trigeminal brainstem nuclei of NMDAR1 knock-out mice. Cell 76:427-437.

Lowe DA, Emre M, Frey P, Kelly PH, Malanowski J, McAllister KI, Neijt HC, Rudeberg C, Urwyler S, White TG, Herling PL (1994) The pharmacology of SDZ EAA 494, a competitive NMDA antagonist. Neurochem Int 25:583-600.

Maurel-Remy S, Bervoets K, Millan MJ (1995) Blockade of phencyclidine-induced hyperlocomotion by clozapine, MDL 100,907 in rats reflects antagonism of 5-HT2A receptors. Eur J Pharmacol 280:R9-R11.

Miyamoto Y, Yamada K, Noda Y, Mori H, Mishina M, Nabeshima T (2001) Hyperfunction of dopaminergic and serotonergic neuronal systems in mice lacking the NMDA receptor $\epsilon 1$ subunit. J Neurosci 21:750-757.

Mohn AR, Gainetdinov RR, Caron MG, Koller BH (1999) Mice with reduced NMDA receptor expression display behaviours related to schizophrenia. Cell 98:427-436.

Monyer H, Sprengel R, Schoepfer R, Herb A, Higuchi M, Lomeli H, Burnashev N, Sakmann B, Seeburg PH (1992) Heteromeric NMDA receptors: molecular and functional distinction of subtypes. Science 256:1217-1221.

Morris RG, Anderson E, Lynch GS, Baudry M (1986) Selective impairment of learning and blockade of long-term potentiation by an $N$-methyl-D-aspartate receptor antagonist, AP5. Nature 319:774-776.

Olney JW, Newcomer JW, Farber NB (1999) NMDA receptor hypofunction model of schizophrenia. J Psychiatr Res 33:523-533.

Ouagazzal A-M, Jenck F, Moreau J-L (2001) Drug-induced potentiation of prepulse inhibition of acoustic startle reflex in mice: a model for detecting antipsychotic activity? Psychopharmacology 156:273-283.

Priestley T, Laughton P, Myers J, Le Bourdelles B, Kerby J, Whiting PJ (1995) Pharmacological properties of recombinant human $N$-methyl-Daspartate receptors comprising NR1a/NR2A and NR1a/NR2B subunit assemblies expressed in permanently transfected mouse fibroblast cells. Mol Pharmacol 48:841-848.

Sakimura K, Kutsuwada T, Ito I, Manabe T, Takayama C, Kushiya E, Yagi T, Aizawa S, Inoue Y, Sugiyama H, Mishina M (1995) Reduced hippocampal LTP and spatial learning in mice lacking NMDA receptor $\epsilon 1$ subunit. Nature 373:151-155.

Supplisson S, Bergman C (1997) Control of NMDA receptor activation by a glycine transporter coexpressed in Xenopus oocytes. J Neurosci 17:4580-4590.

Tricklebank MD, Brsitow LJ, Hutson PH, Leeson PD, Rowley M, Saywell K, Singh L, Tattersal FD, Thorn L, Williams BJ (1994) The anticonvulsant and behavioural profile of L-687,414, a partial agonist acting at the glycine modulatory site on the $N$-methyl-D-aspartate (NMDA) receptor complex. Br J Pharmacol 113:729-736.

Tsien JZ, Huerta PT, Tonegawa S (1996) The essential role of hippocampal CA1 NMDA receptor-dependent synaptic plasticity in spatial memory. Cell 87:1327-1338.

Varty GB, Higgins GA (1995) Reversal of a dizocilpine-induced disruption of prepulse inhibition of an acoustic startle response by the 5-HT2 receptor antagonist ketanserin. Eur J Pharmacol 287:201-205.

Wafford KA, Kathoria M, Bain CJ, Marshall G, Le Bourdelles B, Kemp JA, Whiting PJ (1995) Identification of amino acids in the $N$-methylD-aspartate receptor NR1 subunit that contribute to the glycine binding site. Mol Pharmacol 47:374-380. 